\title{
Probe into the Construction of Logistics Management Specialty Cluster in Vocational College
}

\author{
Yun Wang \\ Economics and Trade Department \\ Zhengzhou Electric Power College \\ Zhengzhou, China \\ Wy.ds@yeah.net
}

\author{
Huixia Hao \\ Economics and Trade Department \\ Zhengzhou Electric Power College \\ Zhengzhou, China \\ Hao_huixia@163.com
}

\begin{abstract}
The construction of specialty cluster is essential for the specialty setting, characteristics as well as long term development of Vocational College. With the change of economic growth mode and industrial upgrading, by analyzing the core development power of Vocational College, using the SWOT analysis method to fully analyze the advantages, disadvantages, opportunities, risks, and the internal and external environment of Vocational College, this paper is dedicate to probe into the construction of logistics management specialty cluster, find a way for logistics management specialty cluster construction in Vocational College, and to explore an effective way on to adapt to the requirements of high-end skill talents in regional economic development.
\end{abstract}

Keywords-Vocational college, specialty cluster

logistics management,

\section{INTRODUCTION}

It is one prominent problem that talents-training does not satisfy the need of growing economic: a large number of skilled talents are needed in the industrial transformation and upgrading; but skilled ones is only a small part in the structure. Reforming and development are urgently needed in Vocational College, for training talents of a larger scale and higher-quality skills. The key is to form a teaching cluster of some key specialties, supported by relevant specialties, to represent the whole teaching standards and the basic characteristics, is needed to train talents that the force market is craving for, such is a guarantee of long-term survival and development of Vocational College.

\section{CORE DEVELOPMENT FORCE AND SPECIALTY CLUSTER CONSTRUCTION OF VOCATIONAL COLLEGE}

\section{A. Core development force of vocational college}

Different from enterprise, the core development force of Vocational College is unique endoplasmic cultural development, it is organized long-term training, implicated in Vocational College organization formed the support in the past, present and future developing of teaching strengths, research strengths, talent strengths, cultural superiority, and then internalized into strategic advantage of sustainable development of Vocational Colleges.

With the development of economy and society, the gap between vocational colleges is not entirely between hard powers, but the core development forces; Apart from scale development, the essential is to reform talents-training mode, to enhance the ability to serve community; different from resource development, it's featured development is brand resources focusing and, enhancement of the strengths of the resources into college culture.

\section{B. Construct specialty cluster is an important way to} nurture Vocational College's core development force

Specialty cluster, is made up of one or more key specialties with high teaching capabilities and high employment rate graduations, of several specialties that of same engineering objects, close technical areas or specialized disciplines of similar basis. The construction of specialty cluster is college internal resources to further integration and innovation. Construction of Vocational College specialty cluster favor the advantages of specialties, and enhance the adaptability of the market; help to integrate the advantages of teaching team, specialty competitiveness; conducive to form specialty features and brand advantages; conducive concentrate on improving the practice teaching conditions, reduce the cost of training, sharing of resources.

Vocational College needs to construct a number of key specialty clusters, to play their leading role of radiation, highlight college characteristics.

\section{CONSTRUCTION OF LOGISTICS MANAGEMENT SPECIALTY CLUSTER IN VOCATIONAL COLLEGE}

\section{A. Logistics industry and logistics management talent needs}

The logistics industry is logistics resource industrialization and formation of compound industries, has knowledge-intensive, technology-intensive, capitalintensive and labor-intensive characteristics. Logistics resource, include transportation, warehousing, loading and unloading, handling, packaging, distribution processing, information platform. Modern logistics industry is called "the third profit source" in promoting the national economy growth. But contradiction about specialized logistics talents shortage has become increasingly prominent with the rapid development of China's logistics industry, logistics relates to all aspects of procurement, production, storage, sale, transportation and distribution, both commercial enterprises and logistics enterprises are facing the logistics process reengineering, and the shortage becomes the 
bottleneck in developing logistics industry. Anyway, logistics technological progress is the driving force to achieve economic growth and development of logistics industry, which stimulates demand for specialized logistics talents not only from amount, but also higher requirements from quality.

Logistics management ask students to master basic theory of logistics management, know logistics regulations, policies, warehouse management, transportation management, materials planning, inventory control, marketing, logistics information management, professional competence and foreign language, can be engaged packaging, distribution, warehousing, multimodal transport, procurement, freight forwarding, information processing business operation and management. Training students for the aim of economic efficiency, able to use modern management theory and methods to plan, design, organize, and operate logistics activities. Logistics industry in China can not develop without skilled talents. Determined by the features of logistics industry, what logistics enterprise need are not personnel of single knowledge structure but also high-quality specialized talents who can completely control logistics operational skills and management knowledge, can play multiple positions, can monitor, optimize and enhance the whole work process. Of course, logistics management talents should have the ability to innovate, to deal with any changes and emergencies in logistics operational processes.

\section{B. Logistics management specialty cluster construction}

The construction of logistics management specialty cluster in Vocational College needs to reflect and adapt to the requirements of local economic development and industrial transformation and upgrading, to track changes in market demand in a timely manner. And then targeted colleges were run to set up and adjust specialty cluster, radio service-oriented areas, industries, enterprises and rural areas, to enhance students' employability and sustainable development capability.

In the construction of logistics management specialty cluster, adhere to the following principles are essential: (1) Persist in the adaptability principle and service regional economic and social development; (2) Persist in scientific principles and clear the construction direction and school characteristics; (3) Persist in the principle of openness, broaden the talent training way.

\section{PROBE INTO CONSTRUCTION OF LOGISTICS MANAGEMENT SPECIALTY CLUSTER IN THE VOCATIONAL COLLEGE}

\section{A. Regional economic analysis}

1) Henan province is committed to the establishment of international logistics center. "Development planning of modern logistics industry in Henan province ((2010-2015)" presents "Establish Zhengzhou as a leader, to speed up the construction of connected world, radiation inland international logistics center in China's central and western regions, so as to promote the whole development has become a modern logistics industry upland with advanced format, optimized structure, wide radiation and strong competitiveness ", Zhengzhou will be as a "dry port" covering the land-locked, as "Oriental Land" radiating Central Asia and Europe, as well as the international air cargo base and logistics distribution center .

2) Railway logistics developed rapidly in Henan. Henan province is located in the central core region, the geographical condition is superior, three-dimensional network of communication is complete and sound. The main artery of communications of China ,which called "five vertical and seven horizontal", three vertical and three horizontal of them go through Henan Province. Henan province boasts 3 points for a class, 9 two class port, Zhengzhou north railway station is the largest railway marshalling station in Asia, Zhengzhou east railway station is the largest railway less-than-carload freight transfer station and Railway Container Center Station, all these have Henan to become Logistics Center.

Since 2012, the Zhengzhou Railway Bureau develop the railway logistics industry vigorously by virtue of location advantages and railway hub advantages. A full range of railway logistics base has been built. In the East, Mingquan special railway lines and logistics base was finished; In the west, the construction of Sanmenxia coal base and Gongyi container logistics base in is being built; In the south, Xinzheng coal base and Xuchang grain logistics park under construction; In the north, Jiaozuo Jiufufen railway freight yard and Beizhou logistics park will be put into use; In the middle, Putian railway logistics base has been included in the plan. With the rapid development of China's high-speed rail construction, railway logistics development space of Henan province will be greater.

3) The supporting infrastructure of cold chain logistics in Henan province is consummate, which has a bright future.

a) The position as big province of agriculture of Henan province provides raw materials advantage for the cold chain logistics development. Henan province is a major agricultural province, planting the crop over variety million mu of wheat, corn, cotton, peanuts, high yield and quality of corn has been in continuous rank first in Corn Varieties. In recent years, the province created four grain crop demonstration base of more than 60 including wheat, corn, rice and soybean, Henan Luohe has called "Chinese food city", the city of Shangqiu, Yongcheng has also become the "Chinese flour city". All of these provide the advantages of raw materials for the development of cold chain logistics in Henan province.

b) The government's macroeconomic policy orientation provides policy guidance and support for the development of cold chain logistics in Henan province. In 2010, the national development and Reform Commission issued " promoting the rise of central China in the planning implementation opinions" presented to build in Zhengzhou, Wuhan and other national comprehensive transportation hub has become an important task of China's rise, which release 
a great good news for the development of Henan logistics industry. Henan province is also actively use this good, strive to establish logistics as a pillar industry of Henan economy rising, "The Henan Province modern logistics development planning (2010-2015)" introduced, Henan province should focus on building ten large logistics industry, which placed first is the food cold chain, with the Zhengzhou cold chain logistics center and Luoyang, Luohe, Xuchang, Shangqiu, Hebi and other cold chain logistics node city as the focus, construct the north-south, east-west extension of the "cross" food cold chain logistics.

The development of the agricultural products in Henan enterprises provides a paradigm for the cold chain logistics in Henan. As a famous province for agricultural and sideline products, agricultural enterprises in Henan is developing fast, there are 21 products of 17 agricultural enterprises won the "Chinese famous brand", the 18 leading enterprises trademark was identified as "Chinese well-known trademark". Among them, "Shuanghui", "Zhongpin", "Sanquan" and "Sinian" and other leading enterprises of cold chain logistics in Henan, even the national scope, is come first on the list. Rely on the strong brand advantages and their own logistics, the enterprise logistics are very influential in the industry, playing an exemplary role for the development of cold chain logistics in Henan.

Henan Province logistics industry has been developing rapidly, logistics services have increasingly diversified, integrated logistics services will be widely applied based on modern information technology and management technology; Logistics industry speeds up the pace of technical progress and innovation, bringing about a growing demand for different levels of logistics talents, as well as high requirements on logistics talents' knowledge and ability structure.

\section{B. SWOT analysis}

As vocational colleges in Henan, specialties arrangement and construction should correlate with their own characteristics, based on the development of local economics and center around the industrial structure and the mainstay industries of Henan, to set major specialty and expand the construction of specialty cluster.

With the help of disciplines in management and using SWOT methods, this paper is analyzing the construction of logistics management specialty cluster (direction) of Zhengzhou Electric Power College (ZZEP), as shown in the following table.

TABLE I. LOGISTICS MANAGEMENT SPECIALTY CLUSTER (DIRECTION) CONSTRUCTION OF SWOT ANALYSIS AND STRATEGY

\begin{tabular}{|c|c|c|}
\hline \multirow{2}{*}{$\begin{array}{r}\text { Internal } \\
\text { resources }\end{array}$} & STRENGTHS (S) & $\begin{array}{c}\text { WEAKNESSES } \\
(\mathbf{W})\end{array}$ \\
\cline { 2 - 3 } & $\begin{array}{c}\text { a. The geographical } \\
\text { position: the college is } \\
\text { located in Zhengzhou } \\
\text { which is the center of } \\
\text { the Central Plains and } \\
\text { the national logistics } \\
\text { hub. }\end{array}$ & $\begin{array}{c}\text { a. The scale is } \\
\text { relatively small }\end{array}$ \\
\hline
\end{tabular}

\begin{tabular}{|c|c|c|}
\hline & $\begin{array}{l}\text { b. The college has a } \\
\text { long history, strong } \\
\text { teachers, and relying on } \\
\text { the electric power } \\
\text { industry }\end{array}$ & $\begin{array}{l}\text { b. Training base is } \\
\text { insufficient }\end{array}$ \\
\hline & $\begin{array}{c}\text { c. Logistics } \\
\text { management is key } \\
\text { provincial-level, trying } \\
\text { to build a provincial } \\
\text { training base. }\end{array}$ & $\begin{array}{l}\text { c. School-enterprise } \\
\text { cooperation, work- } \\
\text { study combination } \\
\text { is not deep enough. }\end{array}$ \\
\hline & $\begin{array}{c}\text { d. Logistics } \\
\text { management lack of } \\
\text { railway logistics and } \\
\text { cold chain logistics in } \\
\text { training logistics talents } \\
\text { in peer institutions of } \\
\text { the province. }\end{array}$ & $\begin{array}{l}\mathrm{d} \text {. The school } \\
\text { belongs to the } \\
\text { electric power } \\
\text { industry, mainly } \\
\text { related in electrical } \\
\text { engineering. }\end{array}$ \\
\hline $\begin{array}{l}\text { OPPORTUNITIES } \\
(\mathrm{O})\end{array}$ & $\begin{array}{c}\text { Take the opportunities } \\
\text { and make use of } \\
\text { advantages }\end{array}$ & $\begin{array}{c}\text { With the help of the } \\
\text { opportunities to } \\
\text { overcome } \\
\text { weaknesses }\end{array}$ \\
\hline $\begin{array}{l}\text { a) National and } \\
\text { provincial pay } \\
\text { importance on } \\
\text { vocational education } \\
\text { b). Central Plains } \\
\text { Economic Zone } \\
\text { industry agglomeration } \\
\text { effect continued and } \\
\text { logistics demand } \\
\text { growing; } \\
\text { c. Three-dimensional } \\
\text { network of } \\
\text { communication is } \\
\text { complete and sound, } \\
\text { logistics distribution is } \\
\text { convenient; } \\
\text { d. The construction of } \\
\text { Henan international } \\
\text { logistics center and } \\
\text { Zhengzhou "dry port". }\end{array}$ & $\begin{array}{l}\text { a. Taking the } \\
\text { opportunity of Central } \\
\text { Plains Economic Zone } \\
\text { industry agglomeration } \\
\text { to set the direction of } \\
\text { business logistics } \\
\text { management; } \\
\text { b. Take advantage of } \\
\text { the rapid development } \\
\text { of Henan transport hub } \\
\text { railway logistics to set } \\
\text { the direction of railway } \\
\text { logistics management; } \\
\text { c. Take the opportunity } \\
\text { of the development of } \\
\text { local food enterprise } \\
\text { logistics to set the } \\
\text { direction of cold chain } \\
\text { logistics management. }\end{array}$ & $\begin{array}{l}\text { a. Taking } \\
\text { advantage of the } \\
\text { opportunity to build } \\
\text { an international } \\
\text { logistics center in } \\
\text { Henan Province } \\
\text { and Zhengzhou } \\
\text { "dry port", } \\
\text { integrate } \\
\text { international } \\
\text { business specialty } \\
\text { resources, set the } \\
\text { direction of } \\
\text { international } \\
\text { logistics } \\
\text { management; } \\
\text { b. Relying on } \\
\text { industry } \\
\text { educational } \\
\text { advantages, set the } \\
\text { direction of the grid } \\
\text { emergency } \\
\text { logistics; } \\
\text { c. Relying on } \\
\text { government } \\
\text { support, and } \\
\text { gradually expand } \\
\text { the size of school. }\end{array}$ \\
\hline THREATS（T） & $\begin{array}{c}\text { With the help of } \\
\text { advantages to eliminate } \\
\text { the threats }\end{array}$ & $\begin{array}{c}\text { Avoid the } \\
\text { weaknesses and } \\
\text { threats }\end{array}$ \\
\hline $\begin{array}{l}\text { a. The challenges of } \\
\text { logistics talent training } \\
\text { caused by industrial } \\
\text { restructuring of Central } \\
\text { Plains Economic Zone; } \\
\text { b. Lack of } \\
\text { understanding to } \\
\text { college-enterprise } \\
\text { cooperation and } \\
\text { existing talent } \\
\text { consumption high } \\
\text { tendency; } \\
\text { c. Students and parents } \\
\text { prejudice against } \\
\text { vocational education }\end{array}$ & $\begin{array}{l}\text { a. Oriented by talents } \\
\text { demand to construct } \\
\text { logistics management } \\
\text { specialty cluster } \\
\text { (direction); } \\
\text { b. Propagate the } \\
\text { important role of the } \\
\text { vocational education } \\
\text { and the employment } \\
\text { prospects for students. }\end{array}$ & Defensive strategy \\
\hline
\end{tabular}




\section{Probe into the construction of logistics management specialty cluster in Vocational College}

Logistics management is the key specialty in ZZEP, but currently there just only one direction. That is to say, although the employment rate is as high as $99 \%$ have not formed a specialty cluster. Construct logistics management specialty cluster, must rely on their own resources, fully integrate and optimize the internal and external resources. Based on the above SWOT analysis results, the strategy of logistics management specialty cluster (direction) construction of the vocational college, is divided into two steps.

1) The first stage, take SO strategy to build a framework about logistics management specialty cluster (direction). Economy and trade department of ZZEP has set five specialties including logistics management, accounting, marketing, e-commerce and international business. Those specialties are highly correlated which can also be said that different segments of the common services in local industrial chain, have common professional skills. Specialty cluster (direction) construction can be expanded on the basis of it, combined with location advantages and college advantages.

Specifically, it can be considered logistics management as key to construct a specialty cluster, together with the international business, ecommerce, integrate superior resources, such as teacher team, school training facilities, school-enterprise cooperation resources etc. Logistics management specialty cluster (direction) can be set the following three directions: industrial and commercial enterprises logistics management, the railway logistics management, third-party logistics management. Under the existing enrollment scale, students in the first two semesters learn basic courses and specialized courses, third semester learn specialized logistics management courses such as operations research, warehousing, supply chain and logistics distribution practice, on third semester final they asked to choose specialty direction. Based on the direction choices, a more targeted teaching in small classes would carried out on fourth to fifth, at last a framework of logistics management with "one core, three directions" formed.

2) The second stage, the WO strategy, with the opportunity to overcome weaknesses. In addition to the training of basic operation in logistics management and front-line workers, vocational college should be positioned in enterprise logistics, as well as the first-line operation of international logistics . Based on the first phase of training, expand the logistics management enrollment scale, and further improve the construction of logistics management specialty cluster with the economic development of Henan Province: It is the time to integrate international business specialty resources and set the direction of international logistics management at the point of building an international logistics center in Henan Province and Zhengzhou "dry port"; Grasp the opportunity of food enterprise logistics development in Henan Province to set cold chain logistics management direction. Ultimately the college logistics management specialty cluster building framework as shown in the following table.

TABLE II. FRAMEWORK OF LOGISTICS MANAGEMENT SPECIALTY CLUSTER

\begin{tabular}{|c|c|c|}
\hline $\begin{array}{c}\text { Specialty } \\
\text { cluster name }\end{array}$ & Direction & Employment direction \\
\hline \multirow[t]{4}{*}{$\begin{array}{c}\text { logistics } \\
\text { management }\end{array}$} & $\begin{array}{l}\text { Industrial } \\
\text { and } \\
\text { commercial } \\
\text { enterprise } \\
\text { logistics } \\
\text { management }\end{array}$ & $\begin{array}{l}\text { Warehousing, distribution, } \\
\text { transportation, freight forwarding and } \\
\text { some post operation and } \\
\text { comprehensive management work; } \\
\text { Procurement, material planning, } \\
\text { inventory control, warehouse } \\
\text { management and some post operation } \\
\text { and comprehensive management work }\end{array}$ \\
\hline & $\begin{array}{c}\text { Railway } \\
\text { Logistics } \\
\text { Management }\end{array}$ & $\begin{array}{l}\text { Railway, highway, port city, city light } \\
\text { rail, subway and other large } \\
\text { enterprises engaged in the transport } \\
\text { sector, transport, planning and } \\
\text { dispatching and command, and local } \\
\text { transportation and production } \\
\text { management }\end{array}$ \\
\hline & $\begin{array}{c}\text { International } \\
\text { Logistics } \\
\text { Management }\end{array}$ & $\begin{array}{l}\text { Jobs like tally、 damage cargo }, \\
\text { documents and tickets、Customs } \\
\text { clearance、 inspection declaration; } \\
\text { Container yard, shipping agency, } \\
\text { freight forwarding services, company } \\
\text { shipping }\end{array}$ \\
\hline & $\begin{array}{c}\text { Cold chain } \\
\text { Logistics } \\
\text { Management }\end{array}$ & $\begin{array}{l}\text { Cold chain logistics enterprises, cold } \\
\text { storage, refrigerated transport } \\
\text { companies, the fresh cargo transport } \\
\text { enterprise, cold chain production } \\
\text { enterprise logistics department, fresh, } \\
\text { food supermarket }\end{array}$ \\
\hline
\end{tabular}

\section{REFERENCES}

[1] Jack Rmeredith. Transport and regional economic competiveness in th global economy [J]. Joural of Transport Geography 2004.12:341342

[2] John A.Gretes and Miehel Green. Improving Undergraduate Learning with Computer-Assisted Assessment[J]. Journal of Reserch on Computing In Education,2000, Vol 33. No l.

[3] Zhongxiao Wang, Quan Lin. Thinking of Vocational College and Specialty cluster construction[J], North Economic and Trade, 2011.12.

[4] Jian Zhao. The development of logistics industry cluster on the construction of logistics specialty cluster -- Taking Chongqing city logistics industry cluster as an example [J], Joural of Chongqing College of Electronic Engineering, 2010.6

[5] Haohui Wang. Strengthening the construction of specialty cluster is an effective way to leapfrog development of vocational education [J], Journal of Bayin Guoleng Vocational and Technical College, 2012.2.

[6] Taylor, Lyndal. Reflecting On Teaching :The Benefits Of SelfEvaluation. Assessment \& Evaluation in Higher Education,,1994.8:109-121. 